\title{
Cerrahi çıkık, Ganz osteotomisi ve femur başı rekonstrüksiyon teknikleri
}

\section{Surgical dislocation, Ganz osteotomy and femoral head reconstruction techniques}

\author{
Lorenz Büchler \\ Spitalzentrum Biel Ortopedi Kliniği, İsviçre \\ Orthopaedic Clinic, Spitalzentrum Biel, Switzerland
}

K alça eklemi artritinin bilinen etiyolojileri, kalça displazisi sekeli, ${ }^{[1]}$ osteonekroz, post-travmatik dejenerasyon ya da inflamatuvar artrittir[2] Birçok olguda etiyoloji bilinmez ve idiyopatik olarak adlandırılır. Femoroasetabular sıkışma konseptinin gelişimi $^{[3]}$ ve asetabular retroversiyon, Perthes hastalı̆̆ı ya da SCFE sekeli gibi kalça ekleminin diğer patomekanik durumlarının daha iyi anlaşılmasıyla birlikte; geç gelişen kalça eklemi dejenerasyonu için risk etmenleri bulunmuştur. Kalça Ekleminin Cerrahi Güvenli Çıkığı, ${ }^{[4]}$ Ganz Periasetabular Osteotomisi ${ }^{[5]}$ ve artroskopik uygulamaların ${ }^{[6,7]}$ gelişmesiyle birlikte, kalçanın yeniden şekillendirilmesi ve tekrar uyumlu hale getirilmesi uygulamaları için yeni güçlü araçlar artık bulunur hale gelmiştir. Genişlemiş teorik anlayış ${ }^{[8]}$ ve yeni teknik olanakların birlikteliği, kalça koruyucu cerrahi alanında yeni bir temel oluşturmuştur..$^{[9,10]}$

Eklem koruyucu uygulamalar; semptomatik, eklem kıkırdağı korunmuş ve kalça ya da pelvisin normal anatomisinde değişiklikler bulunan aktif hastalarda endikedir. Üst yaş limiti yoktur, ancak $40-50$ yaş üzeri, ilerlemiş osteoartriti bulunan (Tönnis Evre 2 veya üzeri) ya da fonksiyonel skoru azalmış hastalarda sonuçlar iyi değildir ve konservatif tedavi sonrası total kalça artroplastisi endikasyonu konulabilir.

\section{BERNESE PERIASETABULAR OSTEOTOMISi (PAO)}

Ganz ve arkadaşlarına ${ }^{[5]}$ göre PAO, asetabulumun tekrar uyumlu hale getirilmesi için çok amaçlı bir tekniktir. PAO için endikasyonlar; büyüme plaklarının kapanması sonrası kalçanın rezidüel semptomatik displazisi, asetabular retroversiyon ${ }^{[11]}$ ve asetabular protrüzyondur. Kan dolaşımı korunurken, geniş,
$\mathbf{K}$ nown etiologies of arthritis of the hip joint are residual dysplasia of the hip, ${ }^{[1]}$ osteonecrosis, post traumatic degeneration or inflammatory diseases. ${ }^{[2]}$ In many cases the etiology remains unknown and the disease was labeled idiopathic. With the development of the concept of femoroacetabular impingement ${ }^{[3]}$ and better understanding of other patho-mechanical situations of the hip joint such as acetabular retroversion, residual Perthes disease or SCFE, potential risk factors for later development of hip joint degeneration were found. With the development of the Safe Surgical Dislocation of the Hip, ${ }^{[4]}$ the Ganz Periacetabular Osteotomy ${ }^{[5]}$ and arthroscopic procedures, ${ }^{[6,7]}$ new powerful tools for hip reshaping and reorientation procedures became available. The combination of a broadened theoretical understanding ${ }^{[8]}$ with new technical possibilities created the base for a new area of hip preserving surgery. ${ }^{[9,10]}$

Joint preserving procedures are indicated in symptomatic, active patients with preserved joint cartilage and an alteration of the normal anatomy of the hip or pelvis. An upper age limit does not exist, but in patients older than 40-50 years with advanced osteoarthritis (Tönnis Grade 2 or more) or a reduced functional score, results are less favorable and a conservative treatment with possible later THR is indicated.

\section{BERNESE PERIACETABULAR OSTEOTOMY (PAO)}

The PAO according to Ganz et al. ${ }^{[5]}$ is a versatile technique for reorientation of the acetabulum. Indications for PAO include symptomatic residual dysplasia of the hip after closure of the growth plates, acetabular retroversion $^{[11]}$ and acetabular protrusion. A large, entirely

- Illetişim adresi: Dr. Lorenz Büchler, Orthopaedic Clinic, Hospital of Biel, 2502 Biel, Switzerland Tel: +4132324 2212 E-mail: lorenz.buechler@insel.ch

- Geliș tarihi: 23 Ocak 2015 Kabul tarihi: 23 Ocak 2015 
tamamen hareketli bir asetabular parça oluşturulur. ${ }^{[12]}$ Arka kolon ve gerçek pelvisin şekli korunur. PAO'nun 20 yıllık takibinde, etkilenen kalçanın sağkalımında \%61'e kadar iyi ve mükemmel sonuçların olduğu bildirilmiştir. ${ }^{[10]}$.

\section{ASETABULAR RETROVERSIYONUN TEDAVISINDE PAO TEKNIĞi}

Hasta, genel anestezi altında, kas gevşetici yapılmış olarak radyolusen masada supin yatırılır.

İşlem, modifiye Smith-Peterson yaklaşımıyla yapılır. Cilt inguinal kıvrımdan açılır. Tensör fasya lata üzerindeki fasya açılır ve tensör kası laterale ekarte edilirek sartorius ve tensör kasları arasında bir klivaj oluşturulur. Proksimalde, abdominal kaslar iliak kanattan sıyrılır. İnguinal bağ ve sartorius kasının tendonunun kesilmesiyle yaklaşımın iki ucu birleştirilmiş olur. Rektus tendonu ile iliokapsülaris kası arasındaki klivaj tanımlanır. Alttaki kapsül ve spina iliaka anterior inferior üzerinden iliokapsülaris kasının keskin diseksiyonu ve sıyrılması ile lateralden mediyale doğru yapılır. Rektus femoris kası laterale ekarte edilir. Eklem kapsülü artık ortaya çıkmıştır ve iskium kolu palpe edilene kadar bir makas posteriora ilerletilir. Lateralde, hamstring tendonları siyatik siniri koruyarak lateral manipülasyona engel olur. İskium osteotomisi görülerek kontrol edilemez ve kör olarak ya da skopi kontrolünde yapılır. ilk olarak, infrakotiloid yükseltinin içinden eklem kapsülünün hemen distalinden kısmi osteotomi yapılır. Siyatik siniri korumak için lateral korteks sağlam bırakılır; daha sonra kolayca kırılacaktır. İkinci osteotomi, superior pübik kolun tam osteotomisidir. Femoral nörovasküler yapılar mediyale ekarte edilir ve bir Hohmann ekartörü konularak korunur. Abduktor kaslar spina iliaka anterior superior seviyesinden geçmektedir ve ters bir Hohman ekartörü superior siyatik foramene konularak üçüncü ve dördüncü osteotomiler yapılırken, siyatik sinirin korunması sağlanır. İlk kesi, kesici motorla, pelvis girişinin yaklaşık $1 \mathrm{~cm}$ laterali hedeflenerek düz olarak yapılır. İkinci kesiye eğik osteotomla devam edilir, büyük siyatik çentiğe $2 \mathrm{~cm}$ mesafeden iskial çıkıntıya $110-120^{\circ}$ açıyla yapılır. Böylece arka kolon sağlam bırakılır.

Asetabular parçayı mobilize etmek için supraasetabular kemiğe 5 mm'lik Shanz çivisi gönderilir ve kalan kemik parça siyatik çentikten kırılır. Asetabular parça artık serbest olarak hareket edebilir ve istenen yönde tekrar yerleştirilebilir. Parça, iki adet $2,5 \mathrm{~mm}$ yivli Kirschner teliyle geçici olarak tespit edilir. Ameliyat sırasında standart bir pelvis grafisi çekilerek parçanın pozisyonu kontrol edilir. mobile acetabular fragment is created while preserving the blood supply. ${ }^{[12]}$ The posterior column and the shape of the true pelvis remain intact. The PAO has reportedly led to good to excellent results with survivorship of the affected hip up to $61 \%$ at 20 years. ${ }^{[10]}$

\section{TECHNIQUE OF PAO FOR TREATMENT OF ACETABULAR RETROVERSION}

The patient is positioned in a supine position on a radiolucent table under general anesthesia with full muscle relaxation.

The procedure is performed through a modified Smith-Petersen approach. The skin is incised in the inguinal fold. The fascia of the Tensor Fascia Latae is incised and the tensor muscle pulled laterally, developing the interval between the sartorius muscle and tensor muscle. Proximally, the abdominal muscles are detached from the iliac crest. The two parts of the approach are now connected with sharp detachment of the inguinal ligament and the tendon of the sartorius muscle. The interval between the rectus tendon and the iliocapsularis muscle is defined. Sharp dissection and detachment of the iliocapsularis muscle from the underlying capsule and the anterior inferior iliac spine is performed from lateral to medial. The rectus femoris muscle is retracted laterally. The joint capsule is now exposed and a pair of scissors is advanced posteriorly until the ischial ramus is palpated. Laterally, the tendons of the hamstrings prevent lateral manipulation, protecting the sciatic nerve. Osteotomy of ischium cannot be visually checked and is performed blind or under control of image intensifier. First, partial osteotomy is performed just distal to the joint capsule within the infracotyloid groove. The lateral cortex is left in place to protect the sciatic nerve. It will later brake easily. The second osteotomy is the complete osteotomy of the superior pubic ramus. The femoral neurovascular structures are retracted medially and protected with the pointed Hohmann retractor. The abductors are tunneled at the level of the ASIS and a reversed Hohmann retractor is introduced into the superior sciatic foramen to protect the sciatic nerve during the execution of the following third and fourth osteotomy. The first cut is performed with an oscillating saw, aiming straight about $1 \mathrm{~cm}$ lateral to the pelvic brim. The second cut is continued with a curved chisel, aiming $110-120^{\circ}$ towards the ischial spine with $2 \mathrm{~cm}$ distance to the greater sciatic notch. This leaves the posterior column intact.

To mobilize the acetabular fragment, a $5 \mathrm{~mm}$ Shanz screw is inserted in the supraacetabular bone and the remaining osseous connection towards the ischial spine is broken. The acetabular fragment can now be 
Kalçanın eklem hareket açıklığı test edilir. $30^{\circ}$ ve $90^{\circ}$ fleksiyonda iç rotasyon yapabiliyor olmalıdır. Eğer gerekli görülürse, kapsül açılarak labrum ve baş boyun uyumu değerlendirilerek olası CAM tipi bir femoroasetabular sıkışma tedavi edilebilir. Son olarak, asetabular parça üç adet 3,5 mm kortikal vida ile tespit edilir. Sartorius kası ve inguinal bağ, kemikten geçen sütürler ile başlangıç yerlerine tekrar tespit edilir.

\section{KALÇANIN GÜVENLI CERRAHI ÇIKARILMA TEKNiĞi}

Yetişkin femur başının kan dolaşımı büyük oranda mediyal sirkumfleks arter (MFCA) tarafindan sağlanır. ${ }^{[13]} \mathrm{Bu}$ arterin ve femur başına giden terminal dallarının seyrine dikkat edilerek, kalça, femur başı nekrozu riski olmadan cerrahi olarak güvenli bir şekilde çıkarılabilir. Kalçanın cerrahi olarak çıkarılması tekniği, Ganz'ın tanımladığı şekilde yapılır. ${ }^{[4]}$

Hasta yan pozisyonda, etkilenen kalça serbest şekilde örtülerek hazırlanır. Kesi, trokanter majörün merkezinden geçecek şekilde yapılır. iliotibial bant uzunlamasına kesilir ve proksimalde gluteus maksimus kasının anterior kenarını takip edecek şekilde ilerlenir. Gluteus maksimus ve gluteus medius kasları arasında bir aralık oluşturulur (Gibson aralığı). Daha sonra kalça iç rotasyona getirilir ve trokanter majör osteotomisi yapılır. Kesinin distal noktası, vastus lateralis kasının fasyasının yapışma yeridir. Proksimal noktası ise fossa piriformisin hemen lateralinde, büyük trokanterin ucudur. MFCA'nın terminal dallarının zarar görmemesi için piriformis fossaya girilmemesi önemlidir. Trokanter parçası kaldırılır ve eklem kapsülünün anterior bölümü diseke edilir. Dorsalde, piriformis tendonu bulunur. Bacağın dış rotasyona alınmasıyla piriformis tendonu gevşer. Böylece, piriformis tendonu ve gluteus minimus arasındaki aralık diseke edilir. Gluteus minimus, yavaşça posteriordan anteriora doğru eklem kapsülünden diseke edilir.

Kapsülotomi üç kısımdan oluşur ve $Z$ şeklinde yapılır: illk kısım, iliofemoral bağa paralel olarak, labruma zarar vermemeye dikkat ederek, düz bir kesiden oluşur. Kapsül, dorselde asetabular dudağa paralel olarak yapışma yerinden ayrılır. Anteriorda, kapsül intertrokanterik hat boyunca yapışma yerinden ayrılır. Kalça ekleminin anterior periferik kısmı artık görülebilir hale gelmiştir.

Kalkar bölgesine yerleştirilen eğimli bir kancanın lateral traksiyonu ile aynı anda, kalçaya fleksiyon ve dış rotasyon yapılarak kalça çıkarılır. Bacak, steril bir kılıf içerisinde hastanın karın bölgesinde konumlandırılır. Genellikle güçlü ve sıkı olan ligamentum teres kapitis freely moved and reoriented according to the desired correction. The fragment is provisionally stabilized with two $2.5-\mathrm{mm}$ threaded Kirschner wires. A standardized intraoperative pelvic radiograph is taken to check the position of fragment.

The range of motion of the hip is tested. An internal rotation of $30^{\circ}$ in $90^{\circ}$ flexion should be possible. If necessary, the joint capsule is opened to assess the labrum and head-neck junction to treat impending CAM type FAI. Finally, the acetabular fragment is fixed with three $3.5 \mathrm{~mm}$ cortical screws. The origins of the sartorius muscle and inguinal ligament are reinserted with transosseous sutures.

\section{TECHNIQUE OF SURGICAL DISLOCATION OF THE HIP}

The blood supply to the adult femoral head is assured mainly via the medial circumflex artery (MFCA). ${ }^{[13]}$ Respecting the course of this artery and the terminal branches into the femoral head, the hip can be surgically dislocated without the risk of femoral head necrosis. The technique of surgical dislocation of the hip is performed according to the description of Ganz. ${ }^{4]}$

The patient is in a lateral position, with the affected leg draped freely. The skin incision is centered over the greater trochanter. The iliotibial band is incised longitudinally, proximally following the anterior margin of the gluteus maximus muscle. The interval between the gluteus maximus and gluteus medius is developed (Gibson interval). The hip is then brought into internal rotation and the osteotomy of the greater trochanter is performed. The distal landmark of the incision is the insertion of the fascia of the vastus lateralis. The proximal landmark is the tip of the greater trochanter just lateral to the fossa piriformis. It is important not to penetrate the fossa piriformis, as this might endanger the terminal branches of the MFCA. The fragment of the trochanter is lifted and the anterior portion of the joint capsule is dissected. Dorsally, the tendon of the piriformis muscle is identified. With external rotation of the leg, the piriformis muscle relaxes. This allows dissection of the interval between the piriformis and gluteus minimus. The latter is gradually dissected from posterior to anterior off the joint capsule.

The capsulotomy has three parts and follows a Z-shape manner: The first part consists of a straight section parallel to the iliofemoral ligament, taking care not to damage the labrum. The capsule is then detached parallel to the acetabular rim dorsally. Anteriorly, the capsule is detached along the intertrochanteric line. The anterior peripheral compartment of the hip joint can now be visualized. 
femorisin özel eğimli bir makas yardımıyla kesilmesi gerekir.

Asetabulumun tamamını, femur baş ve boynunu gözlemlemek artık mümkündür.

\section{FEMUR BAŞ VE BOYUN REKONSTRÜKSIYONU CERRAHI TEKNIKLERI}

MFCA, kalça kapsülüne yaklaşık 'saat 11' konumunda girer. ${ }^{[13]}$ Damar, baş boyun bileşkesinden kemiğe giren retinaküler damarların terminal dallarına kadar, femur boynunda bir periost kıvrımının içerisinde uzanır. Femur başının mediyal kısmına ek bir dolaşım desteği de, lateral femoral sirkumfleks arter (LFCA)'den sağlanır. LFCA, kalçanın mediyal sinoviyal kıvrımında uzanır ve femur başına yaklaşık 'saat 5' konumunda girer. ${ }^{[14]}$ Öte yandan, ligamentum teres içerisindeki damarların erişkin kalçasının kan dolaşımında hiçbir önemi bulunmamaktadır. MFCA ve LFCA'nın ikisinin de terminal dallarına dikkat edilerek, avasküler nekroz riski olmaksızın, femur başının şekli düzeltilebilir.

Kalçanın cerrahi olarak çıkarılması sonrasında, eğer gerekli görülürse, asetabular dudak düzeltilebilir. Buna ek olarak, femur başı veya asetabulumdaki kıkırdak defektleri tedavi edilebilir.

Küresel, saydam bir kalıbın yardımıyla, femur başının yuvarlaklığı kontrol edilir. Cam tipi sıkışmada, femur başında, baş-boyun bileşkesinde offset azalması görülür ve genellikle anteriordan laterale, diğer tarafa doğru bir küreselleşme gösterir. Kavisli bir osteotom ya da yüksek hızlı burr ile femur başının asferik olan bölümü düzeltilir.

Legg-Calvé-Perthes hastalığı gibi femur başının daha ciddi deformitelerinde, femur boynunun anterior offset'inin düzeltilmesi sıklıkla yeterli olmaz. Femur başının küreselliğini arttırmak ve femur başının boyutunu küçültmek için, göreceli baş-boyun uzatma ve baş küçültme teknikleri birlikte kullanılabilir. ${ }^{[15,16]}$ Displazik bir asetabulum bulunan olgularda, başın kapsanmasının arttırılması için eş zamanlı PAO uygulanması da gereklidir. ${ }^{[17]}$
The hip is dislocated with lateral traction of a curved hook positioned at the calcar region, and simultaneous flexion and external rotation of the hip. The leg is positioned in a sterile bag on the ventral side of the patient. The often strong and tight ligamentum teres capitis femoris has to be cut with a special curved scissor.

Inspection of the entire acetabulum, the femoral head and femoral neck is now possible.

\section{SURGICAL TECHNIQUES OF FEMORAL HEAD AND NECK RECONSTRUCTIONS}

The MFCA perforates the hip capsule at around the 11 o'clock position. ${ }^{[13]}$ The vessel then lies in a fold of the periosteum of the femoral neck, until the terminal branches form the retinacular vessels, which enter the bone at the head-neck junction. An additional blood supply to the medial aspect of the femoral head is ensured via the lateral circumflex femoral artery (LFCA), which runs in the medial synovial fold of the hip and enters the femoral head at around the 5 o'clock position. ${ }^{[14]}$ The vessels within the ligamentum teres however are of no relevance in the adult hip. Respecting the terminal branches of both the MFCA and LFCA, the shape of the femoral head can be corrected without the risk of avascular necrosis.

After surgical dislocation of the hip joint, correction of the acetabular rim can be performed if necessary. In addition, cartilage defects on the femoral head or the acetabulum can be treated.

With the help of a spherical transparent template, the sphericity of the femoral head is checked. In cam impingement, the femoral head will show a decreased offset at the head neck junction, usually anterior to lateral with an otherwise spherical femoral head. With a curved osteotome or high-speed burr, the a-spherical portion of the femoral head is corrected.

In more severe deformities of the femoral head, such as Legg-Calvé-Perthes disease, anterior offset correction on the femoral neck is often not sufficient. Relative head neck lengthening and head reduction techniques can be combined to reduce the size of the femoral head and improve sphericity. ${ }^{[15,16]}$ In cases with a dysplastic acetabulum, a simultaneous PAO is required to improved head containment. ${ }^{[17]}$ 


\section{KAYNAKLAR / REFERENCES}

1. Tönnis D. Congenital Dysplasia and Dislocation of the Hip in Children and Adults. Berlin Heidelberg: Springer-Verlag; 1984. pp.113-31, 65-71, 370-81.

2. Harris WH. Etiology of osteoarthritis of the hip. Clin Orthop Relat Res 1986;(213):20-33.

3. Ito K, Minka MA 2nd, Leunig M, Werlen S, Ganz R. Femoroacetabular impingement and the cam-effect. A MRIbased quantitative anatomical study of the femoral headneck offset. J Bone Joint Surg Br 2001;83(2):171-6.

4. Ganz R, Gill TJ, Gautier E, Ganz K, Krügel N, Berlemann U. Surgical dislocation of the adult hip a technique with full access to the femoral head and acetabulum without the risk of avascular necrosis. J Bone Joint Surg Br 2001;83(8):1119-24.

5. Ganz R, Klaue K, Vinh TS, Mast JW. A new periacetabular osteotomy for the treatment of hip dysplasias. Technique and preliminary results. Clin Orthop Relat Res 1988;(232):26-36.

6. Philippon MJ, Stubbs AJ, Schenker ML, Maxwell RB, Ganz R, Leunig M. Arthroscopic management of femoroacetabular impingement: osteoplasty technique and literature review. Am J Sports Med 2007;35(9):1571-80.

7. Büchler L, Neumann M, Schwab JM, Iselin L, Tannast M, Beck M. Arthroscopic versus open cam resection in the treatment of femoroacetabular impingement. Arthroscopy 2013;29(4):653-60. CrossRef

8. Ganz R, Leunig M, Leunig-Ganz K, Harris WH. The etiology of osteoarthritis of the hip: an integrated mechanical concept. Clin Orthop Relat Res 2008;466(2):264-72. CrossRef

9. Beck M, Leunig M, Parvizi J, Boutier V, Wyss D, Ganz R. Anterior femoroacetabular impingement: part II. Midterm results of surgical treatment. Clin Orthop Relat Res 2004;(418):67-73.
10. Steppacher SD, Tannast M, Ganz R, Siebenrock KA. Mean 20-year followup of Bernese periacetabular osteotomy. Clin Orthop Relat Res 2008;466(7):1633-44. CrossRef

11. Siebenrock KA, Schaller C, Tannast M, Keel M, Büchler L. Anteverting periacetabular osteotomy for symptomatic acetabular retroversion: results at ten years. The J Bone Joint Surg Am 2014;96(21):1785-92. CrossRef

12. Hempfing A, Leunig M, Notzli HP, Beck M, Ganz R. Acetabular blood flow during Bernese periacetabular osteotomy: an intraoperative study using laser Doppler flowmetry. J Orthop Res 2003;21(6):1145-50.

13. Gautier E, Ganz K, Krugel N, Gill T, Ganz R. Anatomy of the medial femoral circumflex artery and its surgical implications. J Bone Joint Surg Br 2000;82(5):679-83.

14. Kalhor M, Beck M, Huff TW, Ganz R. Capsular and pericapsular contributions to acetabular and femoral head perfusion. J Bone Joint Surg Am 2009;91(2):409-18. CrossRef

15. Ganz R, Horowitz K, Leunig M. Algorithm for femoral and periacetabular osteotomies in complex hip deformities. Clin Orthop Relat Res 2010;468(12):3168-80. CrossRef

16. Ganz R, Huff TW, Leunig M. Extended retinacular softtissue flap for intra-articular hip surgery: surgical technique, indications, and results of application. Instr Course Lect 2009;58:241-55.

17. Siebenrock KA, Anwander $H$, Zurmühle CA, Tannast $M$, Slongo T, Steppacher SD. Head Reduction Osteotomy With Additional Containment Surgery Improves Sphericity and Containment and Reduces Pain in Legg-Calvé-Perthes Disease. Clin Orthop Relat Res 2014. [Epub ahead of print] 